\title{
INFLUENCE OF HOLDING TIME IN THE DIE ON STRUCTURE DEVELOPMENT OF LOW-ALLOYED TRIP STEELS
}

\author{
Hana JIRKOVÁ, Jiří VRTÁČEK, Michal PEKOVIĆ, Štěpán JENÍČEK, Adam STEHLÍK, \\ Karolína BURDOVÁ
}

\begin{abstract}
University of West Bohemia, RTI - Regional Technological Institute, Pilsen, Czech Republic, EU, hstankov@rti.zcu.cz ${ }^{a}, \underline{v r t a c e k j @ r t i . z c u . c z^{b}}, \underline{\text { pekovicm@rti.zcu.cz }}$, jeniceks@rti.zcu.cz ${ }^{d}, \underline{s t e h l i k a @ r t i . z c u . c z^{e}}$, kburdova@rti.zcu.cz
\end{abstract}

https://doi.org/10.37904/metal.2019.851

\begin{abstract}
Press hardening is a modern forming technology for the production of shaped sheet parts. Its use has been growing in recent years because of its high production accuracy, reduced spring back effect and lower forming forces. This technology is also suitable for high strength TRIP steels (transformation induced plasticity). However, with dies at room temperature, undesirably high cooling rates are obtained, leading to the formation of martensitic structures with a low ferrite content. These structures possess high strength but low ductility. It is therefore important to interrupt the press hardening operation at the right time or even carry out additional heat treatment in a furnace.

Two low-alloy TRIP steels with a carbon content of $0.2 \%$ and different niobium levels were selected for this experiment. At the first stage, the sheets were press-hardened between dies of a hydraulic press. The holding time was varied from 0 to $10 \mathrm{~s}$ and the sheet temperature after removal from the dies was measured with a thermal imaging camera. At the second stage, press hardening in a flat press hardening tool was followed by isothermal holding in a furnace. Mixed structures of martensite, bainite, proeutectoid ferrite and retained austenite were obtained when parameters were chosen properly.
\end{abstract}

Keywords: TRIP steel, multiphase structure, press hardening

\section{INTRODUCTION}

One of the available options, when it comes to reducing the weight and fuel consumption of vehicles to improve safety of passengers [1-3], is the use of car body parts of high-strength steels. In such a case, reduced emissions are an additional and today's highly relevant benefit.

Sheet parts for the car body are mostly produced by press hardening. It is a modern forming method which is suitable for a variety of steels, including high-strength martensitic steels for high-precision parts with low springback [2-4]. Since a variety of mechanical properties are required across the car body, these parts are also made of a wide range of materials. In the materials for the passenger compartment, high ultimate strength is required, which calls for martensitic steels with ultimate strengths of $1500 \mathrm{MPa}$ and higher [5]. On the other hand, the demands on toughness are low in this part of the structure. By contrast, the car's crumple zones require high-ductility and crash-energy-absorbing materials. TRIP steels are a choice which meets these conditions [5]. When cold-deformed, these steels exhibit strain-induced plasticity (the TRIP effect) manifested by absorption of energy and by transformation of retained austenite to martensite [6-8]. The difficulty with these steels is their treatment which should produce a multiphase microstructure consisting of ferrite, bainite, a small amount of martensite and retained austenite. In order to achieve this goal, the rate of cooling in press hardening tools should be reduced, or the workpiece should be removed from the tools, which are at room temperature, before it cools below the Ms. The workpiece can then be held at a certain temperature to ensure that retained austenite becomes stable and that an amount of bainite forms. Hence, several processing parameters need to be optimised to obtain the desired multiphase microstructure with an optimal distribution of structure constituents $[9,10]$. 


\section{EXPERIMENTS}

In multiphase TRIP steels, the rate of cooling through the ferritic and pearlitic transformation regions is of major importance. The cooling rate must be sufficient to prevent the formation of pearlite, which is undesirable in TRIP steels, as it uses up carbon at the expense of stabilisation of retained austenite. Yet, cooling must be interrupted above the $M_{s}$, to ensure that the amount of newly-formed martensite is not excessive because martensite provides high strength but reduces ductility. In the press hardening of sheet products using tools at room temperature, the workpiece must be removed from the tooling early for either isothermal treatment in a furnace or slow and controlled cooling. It will produce the appropriate multiphase structure with the desired mechanical properties and high elongation. In this study, appropriate press hardening times in dies at room temperature were sought experimentally for two multiphase TRIP steels.

Both steels belonged to a class of low-alloy multiphase steels. They were CMnSi and CMnSiNb steels containing $0.2 \%$ carbon, and additions of manganese and silicon (Table 1). The reason for choosing steels with manganese and silicon was that these elements enhance the stability of retained austenite and solid solution strengthening [6,7]. CMnSiNb also contained niobium which contributes to recrystallisation, appropriate grain size development, transformation behaviour and the desired characteristics of retained austenite $[8,11,12]$.

The steels were supplied in the form of $1.8 \mathrm{~mm}$ cold-rolled sheet. They were produced by cutting up ingots and hot rolling the resulting segments to $5.8 \mathrm{~mm}$ thickness. After grinding and descaling, the semi-finished products were cold rolled to the final thickness of $1.8 \mathrm{~mm}$. Before the actual experimental heat treatment, the sheets were annealed at $900^{\circ} \mathrm{C}$ for 30 minutes. Blanks $100 \mathrm{~mm}$ in length were cut from the sheet stock.

The annealed microstructure consisted of ferrite and lamellar pearlite. No effect of niobium was manifested in hardness: both steels showed values of $180-190 \mathrm{HV} 10$. Neither was it apparent in phase transformation calculations performed using JMatPro software. The $\mathrm{Ms}_{\mathrm{s}}$ temperature of $\mathrm{CMnSi}$ steel was calculated as $360^{\circ} \mathrm{C}$ and that of $\mathrm{CMnSiNb}$ was $370^{\circ} \mathrm{C}$ (Table 1).

Table 1 Chemical composition of experimental steels (wt. \%), phase transformation temperatures $\left({ }^{\circ} \mathrm{C}\right.$ ) and mechanical properties of annealed sheet blanks

\begin{tabular}{|c|c|c|c|c|c|c|c|c|c|c|c|c|c|c|c|}
\hline Steel & $\mathbf{C}$ & $\mathbf{S i}$ & $\mathbf{M n}$ & $\mathbf{P}$ & $\mathbf{S}$ & $\mathbf{C r}$ & $\mathbf{N b}$ & $\begin{array}{c}\mathbf{M}_{\mathbf{s}} \\
\left({ }^{\circ} \mathbf{C}\right)\end{array}$ & $\begin{array}{c}\mathbf{M}_{\mathbf{f}} \\
\left({ }^{\circ} \mathbf{C}\right)\end{array}$ & $\begin{array}{c}\mathbf{A}_{c 1} \\
\left({ }^{\circ} \mathbf{C}\right)\end{array}$ & $\begin{array}{c}\mathbf{A}_{c 3} \\
\left({ }^{\circ} \mathbf{C}\right)\end{array}$ & $\begin{array}{c}\mathbf{H V 1 0} \\
{[-]}\end{array}$ & $\begin{array}{c}\mathbf{R}_{\mathbf{p} 0.2} \\
(\mathbf{M P a})\end{array}$ & $\begin{array}{c}\mathbf{R}_{\mathbf{m}} \\
(\mathbf{M P a})\end{array}$ & $\begin{array}{c}\mathbf{A}_{20 m m} \\
(\%)\end{array}$ \\
\hline $\mathrm{CMnSi}$ & 0.20 & 1.74 & 1.41 & 0.008 & 0.003 & 0.12 & 0.001 & 360 & 246 & 734 & 862 & 190 & 422 & 635 & 27 \\
\hline $\mathrm{CMnSiNb}$ & 0.21 & 1.77 & 1.44 & 0.008 & 0.003 & 0.11 & 0.06 & 370 & 257 & 734 & 861 & 180 & 427 & 627 & 26 \\
\hline
\end{tabular}

\subsection{Determination of appropriate press hardening time}

The experimental programme was conducted in two stages. In the first one, the effects of press hardening times between flat dies of a hydraulic press were explored. The goal was to correlate the time between dies and the sheet temperature and microstructural evolution. Soaking at $950{ }^{\circ} \mathrm{C}$ took 100 seconds. The blank was then removed from the furnace, transferred and placed between dies, which took 5 seconds. It was then held between closed dies for 1, 3, 5, 7 and 10 seconds. Once the dies had opened, the temperature of the entire surface of the blank was measured with a thermal imaging camera. It was important to find the dwell time, upon which the blank temperature drops below the $\mathrm{M}_{\mathrm{s}}$. Final cooling to room temperature took place in the air.

In the second stage, actual press hardening tooling was installed on the press. After reviewing the results of the first stage of experiments, only three press hardening times were chosen for the second stage: 3,5 and 10 seconds. In this case, a longer pause was required for handling the blank and placing it into the tool cavity: seconds. The 3 and 5 -second press hardening operations were immediately followed by holding at $425{ }^{\circ} \mathrm{C}$ in a furnace for 20 minutes. The goal of these sequences was to explore the effect of the press hardening time on microstructural evolution and to test the complete treatment route for multiphase TRIP steels. 


\subsection{Materials characterization}

The post-treatment microstructures of the sheets were examined using Olympus optical microscope (OM) and scanning electron microscopes Zeiss EVO MA (SEM). Hardness was measured on the materials using the $\mathrm{HV} 10$ scale. Room-temperature tensile tests at $0.003 \mathrm{~s}^{-1}$ were performed on miniature specimens with $1.2 \mathrm{~mm}$ $\times 2 \mathrm{~mm}$ and $5 \mathrm{~mm}$ gauge section and length, respectively. Temperatures were measured with FLIR SC 7550 thermal imaging camera at a resolution of 320 points $\times 256$ points.

\section{RESULTS AND DISCUSSION}

In the first stage of experiments, which involved flat dies installed on a hydraulic press, the relationship between the press hardening time and microstructural evolution was studied. The measured temperature of the blanks being placed into the press was $890^{\circ} \mathrm{C}$. After the sequence with a 1-second press hardening time, the CMnSi microstructure was a mixture of bainite and martensite and a small amount of free ferrite (Figure 1a). Its hardness was $360 \mathrm{HV} 10$. When removed from the dies, the sheet had a temperature of $595{ }^{\circ} \mathrm{C}$. After longer press hardening times, the temperatures of the blanks were lower, understandably. After 5 seconds, the temperature was $330^{\circ} \mathrm{C}$; and after 10 seconds it was a mere $207^{\circ} \mathrm{C}$, which is below the Ms. With decreasing temperatures, the resulting fraction of martensite was increasing (Figures $1 \mathbf{b}, \mathbf{c}$ ).
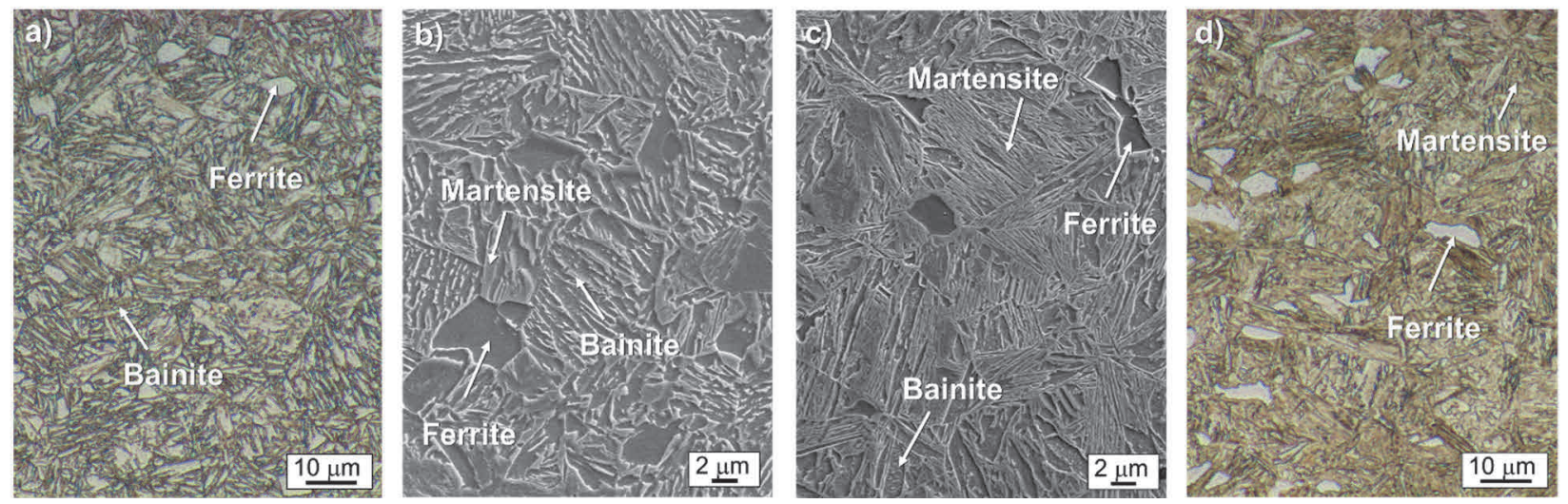

Figure 1 Microstructure of CMnSi steel after press hardening times: a) $1 \mathrm{~s}(\mathrm{OM})$, b) $3 \mathrm{~s}(\mathrm{SEM}), \mathrm{c}) 7 \mathrm{~s}(\mathrm{SEM})$, d) $10 \mathrm{~s}(\mathrm{OM})$
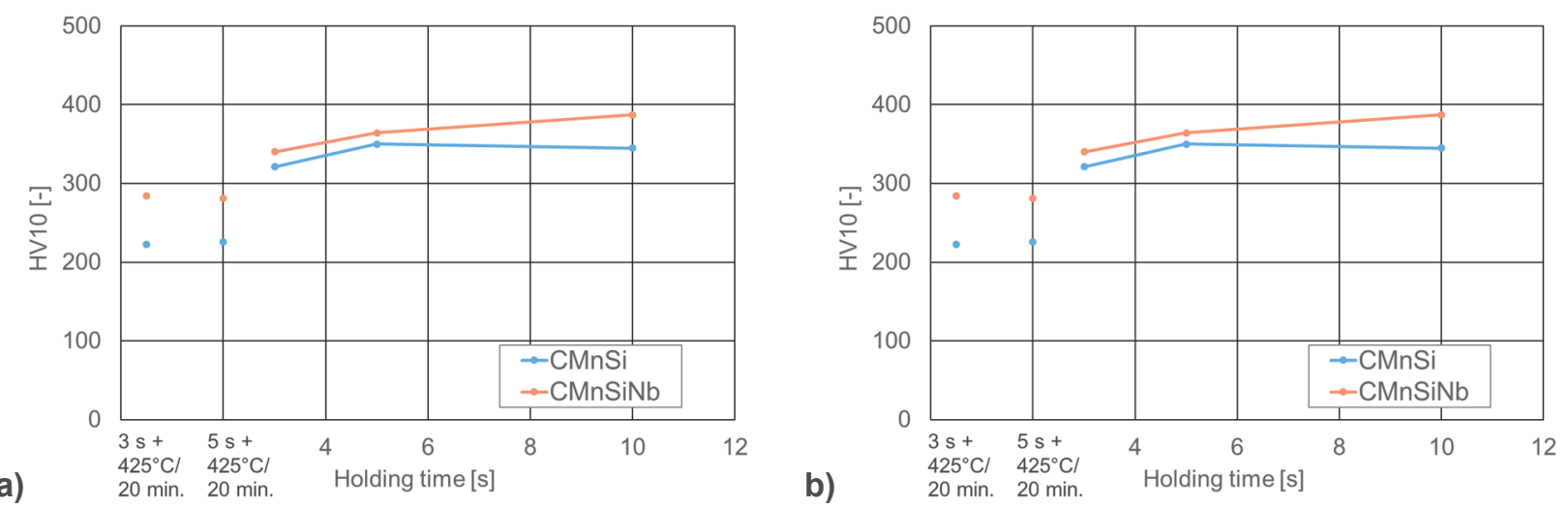

Figure 2 Hardness number HV10 vs. press hardening time (a); Hardness number HV10 after sequences with various press hardening times and with isothermal holding (b)

Martensite began to form along prior austenite grain boundaries. Its increasing amounts were reflected in the increasing hardness: after the sequence with a 10-second press hardening time, it reached $489 \mathrm{HV} 10$ (Figure 2a). Martensite then dominated, the only other phase was a small amount of free ferrite (Figure 1d). 
A similar trend was found in the Nb-microalloyed CMnSiNb steel. After the sequence with a one-second press hardening time, the microstructure was a mixture of bainite, martensite and proeutectoid ferrite. Its hardness was 357 HV10 (Figure 3a). In this material, too, longer press hardening times led to a reduction in the amount of bainite in favour of martensite (Figures 3b-d), which led to the higher hardness of up to 468 HV10 after the sequence with a ten-second press hardening time (Figure $\mathbf{2 b}$ ).
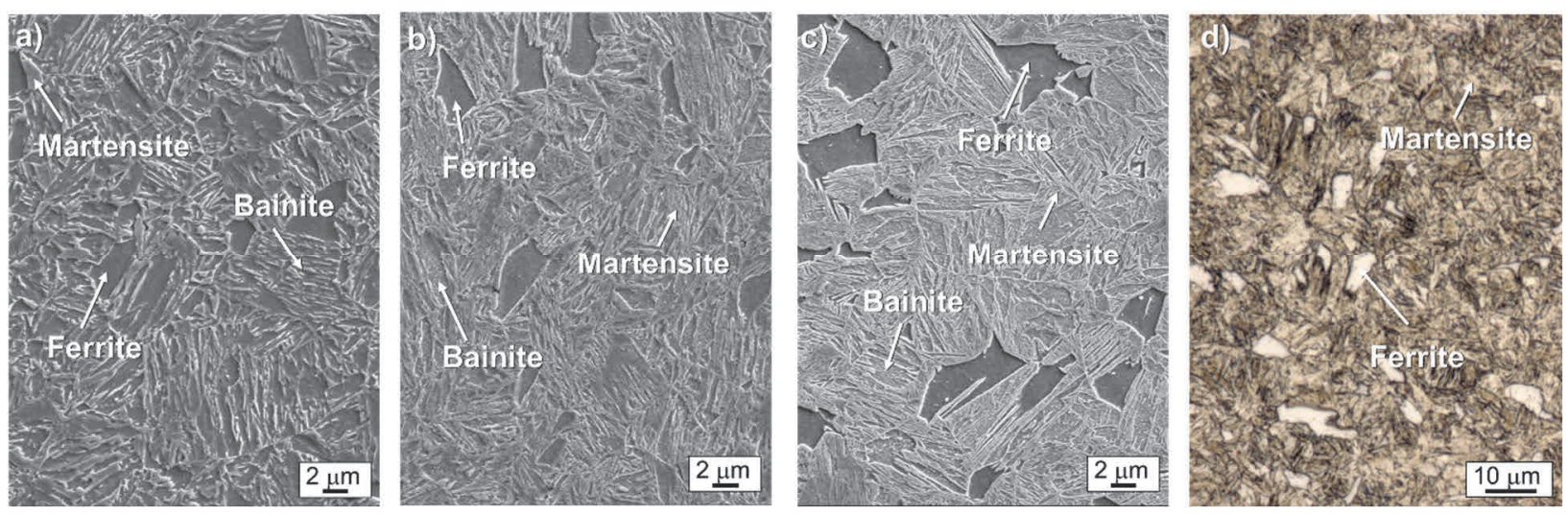

Figure 3 Microstructure of CMnSiNb steel after press hardening times: a) $1 \mathrm{~s}(\mathrm{OM}), \mathrm{b}) 3 \mathrm{~s}$ (SEM), c) $7 \mathrm{~s}$ (SEM), d) $10 \mathrm{~s}(\mathrm{OM})$

Table 2 Heat treatment parameters and mechanical properties

\begin{tabular}{|c|c|c|c|c|c|c|c|}
\hline Steel & $\begin{array}{c}\text { Press } \\
\text { hardening time } \\
\text { (s) }\end{array}$ & $\begin{array}{c}\text { Furnace } \\
\text { temperature } \\
\left({ }^{\circ} \mathrm{C}\right)\end{array}$ & $\begin{array}{l}\text { Holding time in } \\
\text { furnace (min) }\end{array}$ & $\begin{array}{l}\text { HV10 } \\
(-)\end{array}$ & $\begin{array}{c}R_{p 0.2} \\
(\mathrm{MPa})\end{array}$ & $\begin{array}{c}R_{m} \\
(\mathrm{MPa})\end{array}$ & $\begin{array}{c}\text { A5mm } \\
(\%)\end{array}$ \\
\hline \multirow{5}{*}{ CMnSi } & 3 & - & - & 321 & 611 & 1116 & 12 \\
\hline & 3 & 425 & 20 & 222 & 385 & 779 & 38.2 \\
\hline & 5 & - & - & 350 & 616 & 1164 & 17 \\
\hline & 5 & 425 & 20 & 225 & 369 & 785 & 35.2 \\
\hline & 10 & - & - & 345 & 590 & 1117 & 17.5 \\
\hline \multirow{5}{*}{ CMnSiNb } & 3 & - & - & 340 & 988 & 1387 & 21 \\
\hline & 3 & 425 & 20 & 281 & 556 & 865 & 33.8 \\
\hline & 5 & - & - & 364 & 662 & 1236 & 13.3 \\
\hline & 5 & 425 & 20 & 284 & 739 & 1027 & 28.2 \\
\hline & 10 & - & - & 387 & 595 & 1135 & 17.2 \\
\hline
\end{tabular}

Press hardening of $\mathrm{CMnSi}$ in a special tool for five and three seconds produced a ferritic-martensitic structure with hardness levels of 350-321 HV10 (Figure 4a). Thanks to a large amount of martensite, the ultimate strength was higher than $1160 \mathrm{MPa}$. A large ferrite fraction contributed to higher elongation: 12 - $17 \%$ (Table 2). Additional microstructural changes only became apparent after isothermal holding, which followed the press hardening step. Short press hardening and holding at $425^{\circ} \mathrm{C}$ in a furnace for 20 minutes led to a ferritic-bainitic structure with a small fraction of martensite (Figure $\mathbf{4 b}$ ). This change in microstructure led to a drop in hardness to 222 HV10. As the press hardening time was short, the temperature has not decreased below the $\mathrm{Ms}$; holding in the furnace then stabilised retained austenite thanks to enrichment with carbon, and also led to bainite formation. After this sequence, the ultimate strength was below $800 \mathrm{MPa}$, but elongation was appreciably higher: above $35 \%$ (Table 2). For comparison, a sequence with a press hardening time of $10 \mathrm{~s}$ was performed as well. The blank reached the $\mathrm{M}_{\mathrm{s}}$ during press hardening. Its microstructure consisted of martensite and ferrite and had a hardness of 345 HV10 (Figure 4c). Its ultimate strength was $1117 \mathrm{MPa}$ and its elongation reached $17.5 \%$ (Table 2). 

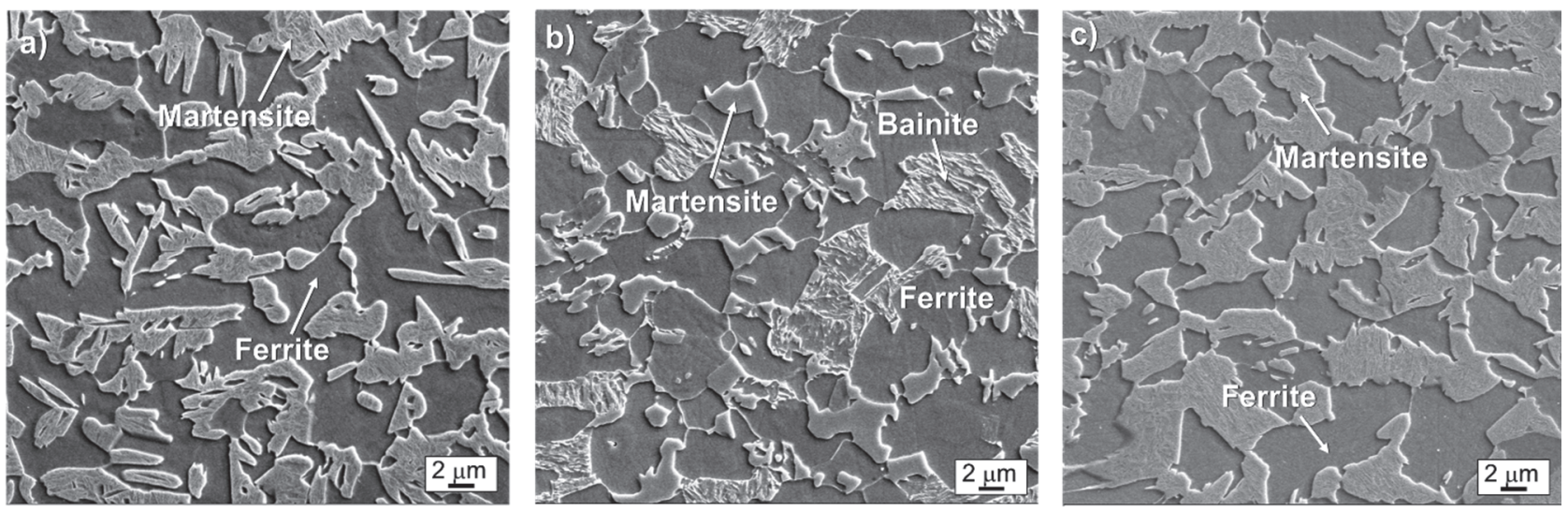

Figure 4 Microstructure of $\mathrm{CMnSi}$ steel after sequences with press hardening times: a) $3 \mathrm{~s}$,

b) $3 \mathrm{~s}+425^{\circ} \mathrm{C} / 20 \mathrm{~min}$. c) $10 \mathrm{~s}$
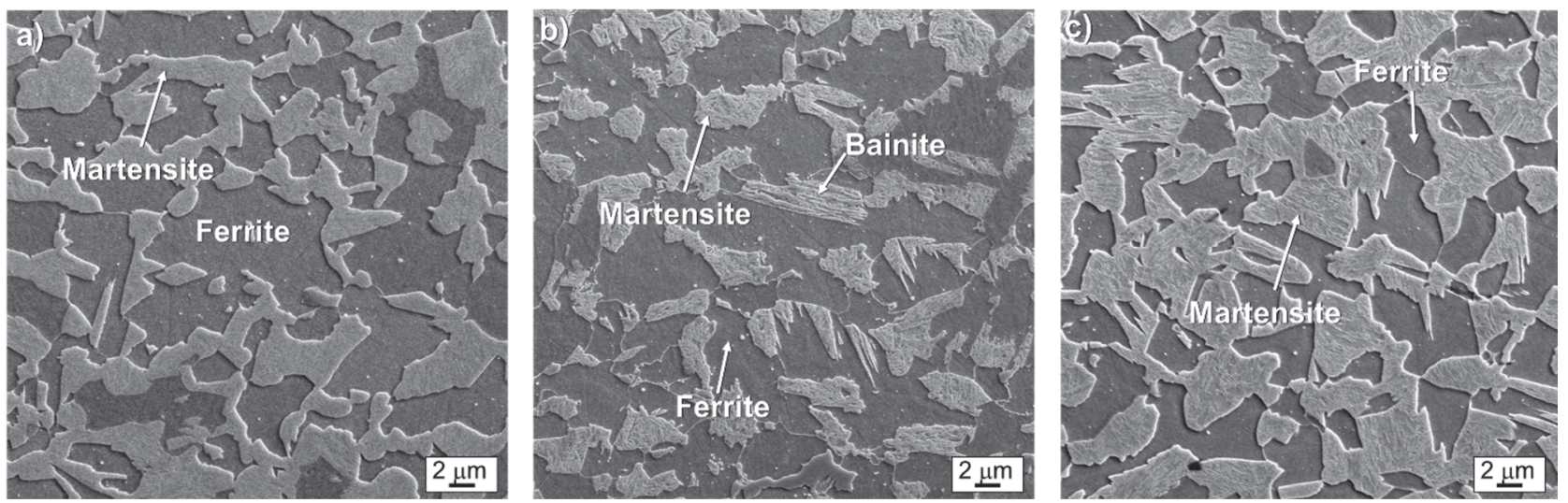

Figure 5 Microstructure of $\mathrm{CMnSiNb}$ steel after sequences with press hardening times: a) $3 \mathrm{~s}$,

b) $3 \mathrm{~s}+425^{\circ} \mathrm{C} / 20 \min$. c) $10 \mathrm{~s}$

Very similar behaviour was observed in $\mathrm{CMnSiNb}$ steel. The press hardening alone produced ferriticmartensitic microstructures, regardless of the dwell time between the dies (Figure 5a, c). Hardness levels were slightly higher than in the other steel: 387 through 340 HV10. Microalloying with niobium led to solid solution strengthening. The ultimate strength was between 1236 and $1387 \mathrm{MPa}$ at elongations up to $21 \%$ (Table 2). When the press hardening step was followed by holding in a furnace, the resulting microstructure was a mixture of ferrite, martensite and bainite (Figure 5b). The martensite fraction was larger than in CMnSi, and the same applied to hardness, $280 \mathrm{HV} 10$, and strength, 865 - $1027 \mathrm{MPa}$ (Table 2). Elongation was approximately $30 \%$.

\section{CONCLUSIONS}

In the present experimental programme, the effects of press hardening time, either between plain dies or a press hardening tool, on microstructural evolution and mechanical properties of blanks from two TRIP steels has been studied. At five-second and longer press hardening times, a martensitic microstructure with ferrite formed and exhibited high hardness up to 489 HV10. At shorter times, one second and three seconds, the final microstructure was a mixture of martensite, bainite and ferrite. When the press hardening operation in a tool at room temperature was followed by isothermal holding, both steels developed larger amounts of bainite and less martensite. CMnSi steel had ultimate strengths approx. $780 \mathrm{MPa}$ and elongation levels higher than $35 \%$. In CMnSiNb, microalloying with niobium led to higher ultimate strength, up to $1027 \mathrm{MPa}$ and elongations around $28 \%$. This experiment demonstrated the viability of press hardening of low-alloy TRIP steels in dies at 
room temperature. It also showed that press hardening combined with subsequent holding in a furnace can produce the required mechanical properties.

\section{ACKNOWLEDGEMENTS}

\section{The present contribution has been prepared with the support of the student grant competition of the University of West Bohemia in Pilsen, SGS 2019-019.}

\section{REFERENCES}

[1] GRAJCAR, A., KUZIAK, R. and ZALECKI, W. Third generation of AHSS with increased fraction of retained austenite for the automotive industry. Archives of Civil and Mechanical Engineering. 2012. vol. 12, pp. 334-341.

[2] LESCH, C., KWIATON, N. and KLOSE, F. B. Advanced High Strength Steels (AHSS) for Automotive Applications - Tailored Properties by Smart Microstructural Adjustments. Steel Research International. 2017. vol. 88, no. 10, pp. 1-21.

[3] MORI, K., BARIANI, P.F., BEHRENS, B.A., BROSIUS, A., BRUSCHI, S., MAENOE, T., MERKLEIN, M. and YANAGIMOTO, J. Hot stamping of ultra-high strength steel parts. CIRP Annals - Manufacturing Technology. 2017. vol. 66, no. 2, pp. 755-777.

[4] SEO, E.J., CHO, L. and DE COOMAN, B.C. Application of quenching and partitioning (Q\&P) processing to press hardening steel. Metallurgical and Materials Transactions A: Physical Metallurgy and Materials Science. 2014. vol. 45, no. 9, pp. 4022-4037.

[5] TAMARELLI, C.M. AHSS 101: The evolving use of advanced high-strength steel for automotive applications. In: Steel Market Development Institute, University of Michigan. 2011, pp. 1-45, Available at: http://www.autosteel.org, [Accessed January 2019].

[6] BLECK, W. Using the TRIP effect - the dawn of a promising group of cold formable steels. In International Conference on TRIP-Aided High Strength Ferrous Alloys. Mainz: GRIPS'sparkling world of steel, 2002, pp. 13-23.

[7] BLECK, W., GUO, X. and MA, Y. The TRIP Effect and Its Application in Cold Formable Sheet Steels. Steel Research International. 2017. vol. 88, no. 10, pp. 1-21.

[8] OHLERT, J., BLECK, W. and HULKA, K. Control of microstructure in TRIP steels by niobium. In International Conference on TRIP-Aided High Strength Ferrous Alloys. Mainz: GRIPS'sparkling world of steel, 2002, $199-206$.

[9] JIRKOVÁ, H., OPATOVÁ, K., KÁŇA, J., BUBLÍKOVÁ, B. and BYSTRIANSKÝ M. Integration of Press-Hardening Technology into Processing of Advanced High Strength Steels. Materials Science Forum. 2018. vol. 941, pp. 317322.

[10] JIRKOVÁ, H., OPATOVÁ, K., KÁŇA, J. and BYSTRIANSKÝ M. Use of the press hardening technology for treatment of TRIP steel. Manufacturing Technology. 2018. vol. 18, no. 2, pp. 243-247.

[11] HONG, S.C., LIM, S.H., HONG, H.S., LEE, K.J., SHIN, D.H. and LEE, K.S. Effects of Nb on strain induced ferrite transformation in C-Mn steel. Materials Science and Engineering A, 2003. vol. 355, pp. 241-248.

[12] PARK, S.H., CHOO, W.Y., KIM, N.J. and KO, J.H. Effects of hot rolling conditions on the microstructure and tensile properties of Nb-bearing TRIP steels. In International Symposium on Hot Workability and Light Alloys Composites, Montreal: TMS of CIM, 1996, pp. 493. 